\title{
Aplikasi Irigasi Portable Sprinkler Pada Tanaman Pakcoy (Brassica JunCea L.) Di DeSA marga Agung Kecamatan Jati Agung Lampung Selatan
}

Utilization of Portable Sprinkle Irrigation System for Pakcoy (Brassica juncea L.): Case of Marga Agung, Jati Agung, Soth Lampung Regency

\author{
Kiki Dwi Okvidiantoro"), Ahmad Tusi ${ }^{2}$, Budianto Lanya ${ }^{2)}$ \\ ${ }^{1)}$ Mahasiswa Teknik Pertanian, Fakultas Pertanian, Universitas Lampung \\ ${ }^{2)}$ Dosen Teknik Pertanian, Fakultas Pertanian, Universitas Lampung \\ e-mail : kikidwidiantoro27@gmail.com
}

\begin{abstract}
ABSTRAK
Mayoritas petani di Desa Marga Agung menggunakan air hujan sebagai sumber air untuk memenuhi kebutuhan air tanaman. Pada musim kemarau, petani tidak dapat melakukan aktivitas budidaya tanaman karena terbatasnya sumber air. Upaya yang dapat dilakukan untuk meningkatkan produksi dan efesiensi pemakaian air irigasi yang tepat guna yaitu dengan menggunakan irigasi sprinkler. Penelitian bertujuan untuk mengetahui kinerja dan aplikasi portable sprinkler pada budidaya tanaman pakcoy (Brassica juncea L.). Hasil menunjukkan laju infiltrasi tanah $(52 \mathrm{~mm} / \mathrm{jam})$ di lokasi penelitian lebih besar dibandingkan laju aplikasi sprinkler sebesar (6.49 mm/jam), sehingga pada saat dilakukan penyiraman tidak terjadi aliran permukaan (run off). Nilai koefisien keseragaman/coeficient uniformity (CU) sebesar $53.13 \%$. Rendahnya nilai koefisien keseragaman yang diperoleh disebabkan karena penggunaan metode single nozzle head sprinkler dan tingginya kecepatan angin yang terjadi di lokasi penelitian sebesar $0.66 \mathrm{~m} / \mathrm{det}$. Hasil produksi tanaman pakcoy sebesar $1.7 \mathrm{~kg} / \mathrm{m}^{2}$ dengan berat per tanaman $70 \mathrm{gram} / \mathrm{tanaman}$.
\end{abstract}

Kata kunci : irigasi portable sprinkler, tanaman pakcoy, pompa.

\section{ABSTRACT}

Generally farmers in Marga Agung village using rain as source to meet the water needs of plants. During the dry season, farmers cannot do cultivation planting activity due to the limited water resources. The effort that can be done to increase production and efficiency of appropriate irrigation use by using sprinkler irrigation. The study aims to determine performance and application of portable sprinkler irrigation on pakcoy (Brassica juncea L.) cultivation. The results showed that the infiltration rate of the soil $(52 \mathrm{~mm} / \mathrm{h})$ at the research area was greater than the application rate $(6.49 \mathrm{~mm} / \mathrm{h})$, so that the run off did not occurred. The coefficient of uniformity $(\mathrm{CU})$ was $53.13 \%$. The low coefficient of uniformity is obtained due to the use of methods of single nozzle head sprinkler and wind speed occurred at the research area is as $0.66 \mathrm{~m} / \mathrm{s}$. The pakcoy crop production was $1.7 \mathrm{~kg} / \mathrm{m}^{2}$ with a weight of 70 grams per plant.

Key words: portable sprinkler irrigation, crop pakcoy, pump.

Diterima : 23 Juni 2016; Disetujui : 25 Agustus 2016 ; Online Published : 31 Oktober 2016

\section{PENDAHULUAN}

Desa Marga Agung merupakan desa yang mayoritas penduduknya bermata pencarian sebagai petani, dari total penduduk sebanyak 4116 jiwa, 3013 jiwa berprofesi sebagai petani. Hal ini menunjukkan bahwa sektor pertanian sangat mendominasi jenis pekerjaan masyarakat sekitar. Untuk itu perlu dilakukan perhatian yang lebih pada aspek pertanian.

30 Aplikasi Irigasi Portable Sprinkler Pada Tanaman Pakcoy (Brassica Juncea L.) Di Desa Marga Agung Kecamatan Jati Agung Lampung Selatan 
Lahan pertanian di Desa Marga Agung termasuk daerah lahan tadah hujan yang hanya mengandalkan sumber air hujan. Sehingga ketika musim kemarau tiba banyak lahan yang tidak dimanfaatkan karena tidak tersedianya pasokan air irigasi. Untuk mengatasi kendala tersebut, petani sayuran di Desa Marga Agung melakukan penyiraman secara manual. Proses penyiraman secara manual tentu memerlukan tenaga ekstra dan waktu tambah bagi petani. Untuk itu, perlu dilakukan upaya untuk mengatasi masalah tersebut. Salah satu upaya yang dapat dilakukan adalah penggunaan teknologi irigasi tepat guna dan hemat air seperti, irigasi curah (sprinkler).

Teknologi irigasi sprinkler dapat memberikan efisiensi dan efektifitas yang cukup tinggi dalam memenuhi kebutuhan air bagi tanaman. Hal ini dapat terwujud jika sistem irigasi sprinkler dapat dirancang dengan tepat, penggunaan yang teratur dan sesuai dengan jumlah kebutuhan tanaman serta waktu pemberian air yang tepat (Hansen et al., 1992). Selain itu, irigasi sprinkler dapat digunakan pada kontur lahan datar maupun lahan berlereng. Kendala lain yang dihadapi oleh petani adalah investasi awal yang cukup besar serta lahan petani yang kecil rata-rata 0.5 .

Oleh karena itu, perlu dilakukan kajian penelitian mengenai penerapan irigasi sprinkler portable (dapat dipindah-pindah) di Desa Marga Agung. Tujuan dari penelitian ini yaitu untuk mengetahui kinerja dan aplikasi portable sprinkler pada budidaya tanaman pakcoy (Brassica juncea L.).

\section{BAHAN DAN METODE}

Penelitian ini dilaksanakan di Desa Marga Agung Kecamatan Jati Agung Lampung Selatan dan Laboratorium Rekayasa Sumber Daya Air dan Lahan (RSDAL) Jurusan Teknik Pertanian Universitas Lampung pada bulan Mei-Juni 2015.

Alat yang digunakan adalah satu unit sistem irigasi sprinkler portable (Tusi, 2013), soil moisture tester, ombrometer (alat ukur curah hujan sederhana), double ring infiltrometer, ring sample, timbangan digital, cangkul kecil, cangkul, can (penampung), penggaris, gelas ukur, kamera, terpal, bambu dan alat tulis. Bahan yang digunakan dalam penelitian ini adalah benih tanaman pakcoy.

\section{Tahapan Penelitian}

Penelitian diawali dengan melakukan pengukuran terhadap data acuan yaitu kondisi iklim lokasi penelitian, sifat fisik tanah dan menghitung laju infiltrasi. Selanjutnya yaitu pengolahan lahan, instalasi irigasi sprinkler serta pengujian kinerja irigasi sprinkler. Kemudian dilanjutkan dengan tahap budidaya tanaman yang meliputi penyemaian benih, pemupukan, pindah tanam, irigasi, pengamatan pertumbuhan, perawatan dan panen.

\section{Variabel Pengamatan}

Variabel pengamatan yang akan diamati meliputi: kinerja sistem irigasi portable sprinkler (koefisien keseragaman, debit, dan laju penyiraman), kebutuhan air tanaman, dan pertumbuhan tanaman (tinggi tanaman, jumlah daun, dan indeks luas daun).

\section{Metode Pengukuran}

\section{Curah hujan}

Pengukuran curah hujan yang terjadi di lokasi penelitian diukur menggunakan ombrometer. Ombrometer yang digunakan dibuat secara sederhana dengan menggunakan corong untuk menangkap hujan dan pipa untuk menampung air hujan dan ditambahkan kran untuk membuka dan menutup air. Corong yang digunakan memiliki diameter $25 \mathrm{~cm}$, tinggi pipa $75 \mathrm{~cm}$, dan diameter pipa sebesar 4 inch (Gambar 1).

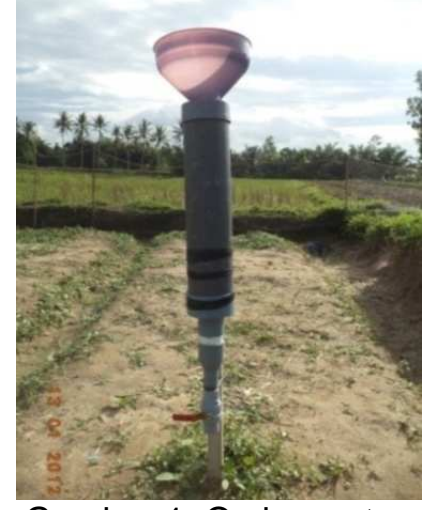

Gambar 1. Ombrometer 


\section{Kecepatan Angin}

Kecepatan angin diukur menggunakan bola-bola gabus. Bola-bola gabus terbuat dari gabus dengan massa 0.57 gram dan panjang tali $30 \mathrm{~cm}$ (Gambar 2). Pengukuran kecepatan angin dilakukan pada saat penyiraman irigasi sprinkler. Pengukuran menggunakan penggaris dengan mengukur simpangan tali gabus dengan tiang penyangga. Selanjutnya, menghitung kecepatan angin yang terjadi pada saat proses penyiraman berlangsung.

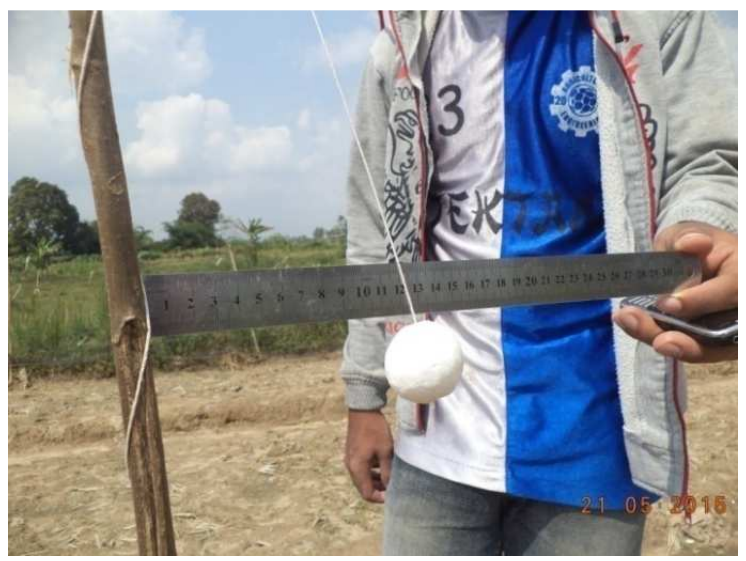

Gambar 2. Pengukuran kecepatan angin

\section{Tekstur Tanah}

Sifat fisik tanah diukur dan penggolongannya digunakan acuan segitiga tekstur tanah USDA (LPT, 1979).

\section{Kadar Air Tanah}

Kadar air tanah diukur sebelum proses penyiraman. Kadar air tanah diukur dengan menggunakan soil moisture tester serta dilakukan setiap pagi hari sebelum irigasi dan setelah irigasi dilakukan.

\section{Infiltrasi}

Pengujian laju infiltrasi dilakukakan menggunakan metode Horton. Menurut Horton kapasitas infiltrasi berkurang seiring dengan bertambahnya waktu hingga mendekati nilai yang konstan (Nining, 2015). Sehingga pengukuran laju infitrasi yang dilakukan mulai pukul 11.00 wib.

\section{Kinerja Sistem Irigasi Sprinkler}

Kinerja sistem irigasi sprinkler ditentukan berdasarkan beberapa parameter ukur. Parameter tersebut yaitu debit, laju penyiraman, dan koefisien keseragaman /uniformity coefficient (CU). Debit sprinkler diukur pada sprinkler terakhir. Pengukuran dilakukan sebanyak tiga kali ulangan dengan tekanan 1 bar. Pengujian keseragaman curah irigasi sprinkler menggunakan metode single nozzle head sprinkler.

\section{HASIL DAN PEMBAHASAN}

\section{Kondisi Iklim Lokasi Penelitian}

1) Curah Hujan

Total curah hujan yang terjadi selama penanaman adalah $28.2 \mathrm{~mm}$ atau dapat memenuhi total kebutuhan irigasi sebesar 44\% dan rata-rata curah hujan adalah $3.13 \mathrm{~mm}$. Kejadian hujan terjadi pada pertengahan penanaman sebanyak sembilan kali hujan dan curah hujan tertinggi pada saat penanaman terjadi pada hari ke-10 sebesar $10 \mathrm{~mm}$ dan curah hujan terendah terjadi pada hari ke dua sebesar $0.1 \mathrm{~mm}$.

\section{2) Kecepatan Angin}

Kecepatan angin rata-rata yang terjadi selama penelitian adalah $0.66 \mathrm{~m} / \mathrm{det}$.

\section{Sifat Fisik Tanah}

1) Struktur Tanah.

Nilai sifat fisik tanah pada lahan penelitian memiliki adalah lempung liat berpasir dengan nilai persentase fraksi pasir $63.3 \%$, fraksi liat $26.6 \%$, dan fraksi debu $10 \%$.

\section{2) Kadar Air Tanah.}

Kadar air tanah di lokasi penelitian memiliki nilai field capasity $\left(\theta_{\mathrm{fc}}\right) 18 \%$ volume, titik kritis $\left(\theta_{c}\right) 15 \%$ volume, dan permanent wilting point $\left(\theta_{\mathrm{pwp}}\right) \quad 8.3 \%$ volume. Nilai-nilai tersebut dijadikan acuan dalam proses irigasi yang dilakukan.

3) Infiltrasi.

Hasil pengukuran laju infiltrasi ditunjukan pada Gambar 3. Laju infiltrasi pada menit awal yang terjadi sangat tinggi, kemudian menurun dengan bertambahnya kelembaban tanah hingga tanah mengalami titik jenuh. Dari kurva tersebut dapat dilihat bahwa laju infiltrasi mulai

32 Aplikasi Irigasi Portable Sprinkler Pada Tanaman Pakcoy (Brassica Juncea L.) Di Desa Marga Agung Kecamatan Jati Agung Lampung Selatan 
konstan pada waktu setelah 0.5 jam dengan laju infiltrasi minimum 52 mm/jam.

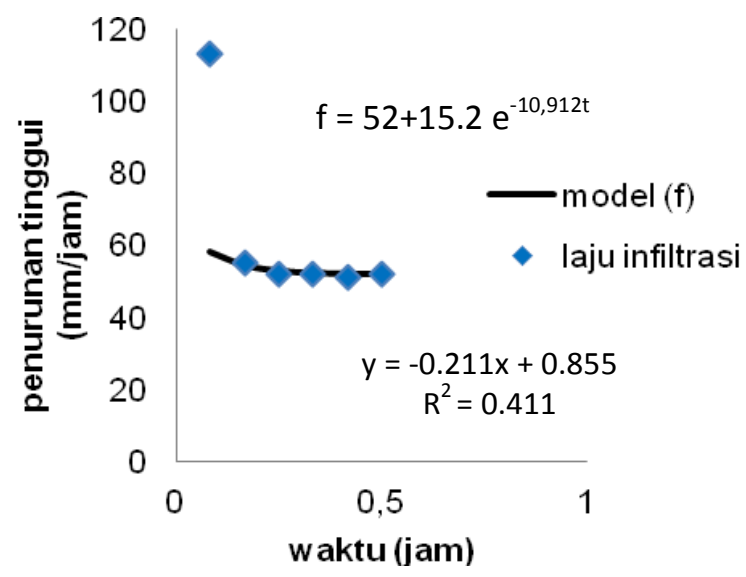

Gambar 3. Persamaan laju infiltrasi

\section{Kinerja Sistem Irigasi Sprinkler}

1) Debit.

Pengukuran debit sprinkler dilakukan pada sprinkler terakhir (paling ujung). Pengukuran dilakukan sebanyak tiga kali ulangan dengan tekanan 1 bar. Hasil perhitungan debit sprinkler adalah 0.18 //det.

Tabel 1. Debit irigasi sprinkler

\begin{tabular}{cccc}
\hline \multirow{2}{*}{$\begin{array}{c}\text { Uji } \\
\text { ke- }\end{array}$} & $\begin{array}{c}\mathrm{P} \\
(\mathrm{bar})\end{array}$ & \multicolumn{2}{c}{ Debit Intensitas penyiraman } \\
\cline { 3 - 4 } & 1 & $(\mathrm{~d} \mathrm{dtk})$ & $\left(\mathrm{m}^{3} / \mathrm{jam}\right)$ \\
\hline 1 & 1 & 0.175 & 0.631 \\
2 & 1 & 0.181 & 0.652 \\
3 & 1 & 0.185 & 0.665 \\
\hline \multicolumn{2}{c}{ Rata-rata } & 0.18 & 0.645 \\
\hline
\end{tabular}

Sumber: analisis data primer 2015

2) Laju Penyiraman.

Hasil pengukuran pada lokasi penelitian menunjukkan bahwa laju penyiraman sebesar $6.49 \mathrm{~mm} / \mathrm{jam}$ dan laju infiltrasi sebesar 52 $\mathrm{mm} / \mathrm{jam}$. Hal tersebut menunjukkan bahwa laju infiltrasi lebih kecil dari laju penyiraman sehingga pada saat penyiraman yang berlebihan akan mengakibatkan aliran permukaan (run off).

3) Koefisien Keseragaman (CU).

Radius pancaran pada sprinkler adalah $8.6 \mathrm{~m}$ dan nilai koefisien keseragaman (CU) rata-rata sebesar $53.13 \%$. Dengan hasil perhitungan nilai koefisien $53.13 \%$ maka dapat diartikan bahwa penyiraman menggunakan irigasi sprinkler memiliki keseragaman penyiraman yang masih dibawah nilai yang disyaratkan (85\%). Hal ini terjadi karena pengujian keseragaman curah irigasi sprinkler menggunakan metode single nozzle head sprinkler, tetapi jika menggunakan metode block square method maka akan menghasilkan tingkat keseragaman yang lebih baik.

Selain itu, menurut Intan (2014) salah satu faktor yang mempengaruhi rendahnya nilai koefisien keseragaman adalah tekanan yang rendah, butiran air yang dipancarkan, dan kecepatan angin yang tinggi saat penyiraman.

\section{Pemberian Air Irigasi Sprinkler}

Penyiraman diberikan ketika kadar air tanah berada di bawah kapasitas lapang. Berdasarkan pengamatan curah hujan dan perhitungan kecepatan angin yang telah dilakukan pada saat penelitian, proses pemberian air irigasi tidak setiap hari dilakukan (Gambar 4).

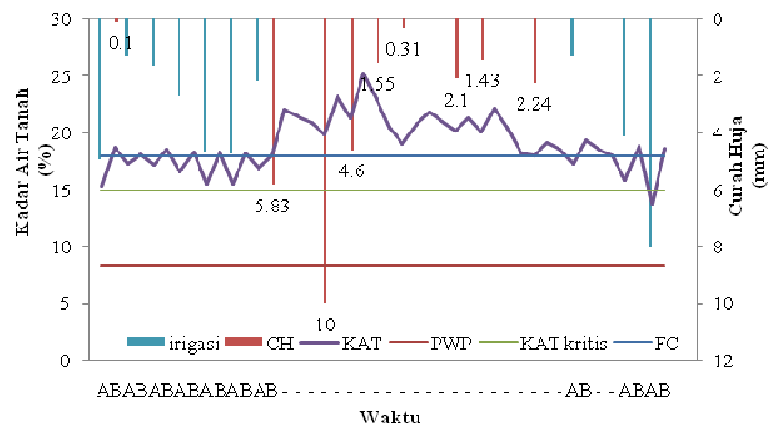

Keterangan:

$A=$ awal irigasi

$B=$ akhir irigasi

Gambar 4. Kebutuhan air tanaman selama penanaman

Gambar 4, menunjukkan bahwa pemberian air irigasi terjadi sejak awal penanaman karena kadar air tanah berada di bawah kapasitas lapang. Total pemberian air irigasi adalah $35.5 \mathrm{~mm}$ atau dapat memenuhi total kebutuhan irigasi sebesar 56\%. Pemberian air irigasi terbesar diberikan pada hari ke-20 karena kadar air berada di titik kritis $13.7 \%$ sebesar $8 \mathrm{~mm}$ dan pemberian air irigasi 
terendah terjadi pada hari kedua dan ketujuh belas sebesar $1.3 \mathrm{~mm}$. Rata-rata pemberian irigasi adalah $3.55 \mathrm{~mm}$. Penyiraman air irigasi yang dilakukan selama penanaman sebanyak 10 kali dengan dengan total lama penyiraman adalah 5.48 jam. Proses irigasi dapat dilihat pada Gambar 5.

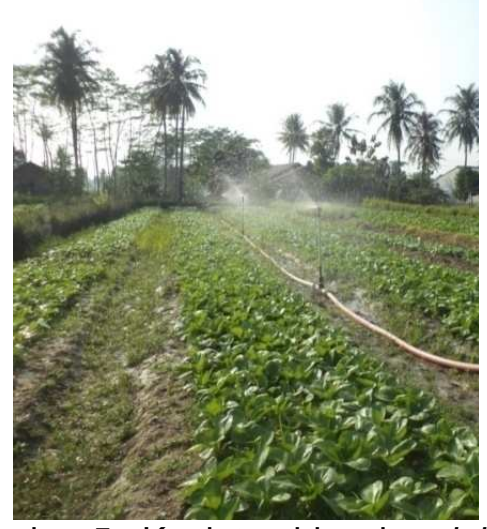

Gambar 5. Kegiatan irigasi sprinkler

\section{Pertumbuhan Tanaman Pakcoy}

1) Tinggi Tanaman

Pertumbuhan tinggi tanaman pakcoy dapat dilihat pada Gambar 6. Tinggi tanaman pakcoy mengalami pertambahan tinggi setiap minggunya. Adapun tinggi tanaman pakcoy rata-rata pada minggu pertama adalah 5.83 $\mathrm{cm}$, pada minggu kedua adalah $11.46 \mathrm{~cm}$, dan pada minggu ketiga adalah $21.29 \mathrm{~cm}$. Plot satu mengalami pertumbuhan paling tinggi dari plot yang lain. Hal ini disebabkan karena penempatan plot satu diantara dua sprinkler sehingga dapat menerima air irigasi secara optimal.

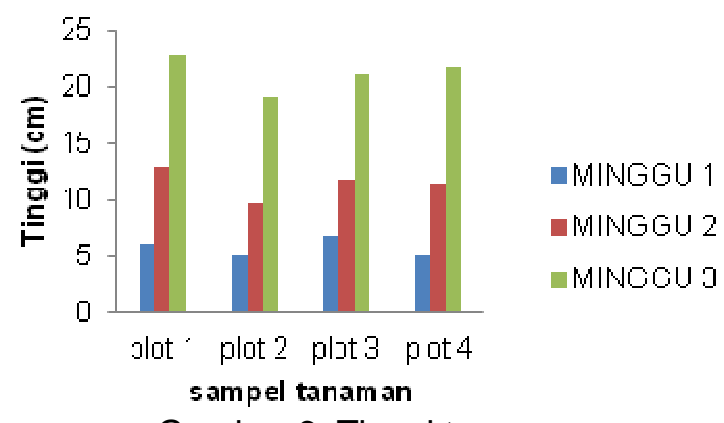

Gambar 6. Tinggi tanaman
2) Jumlah Daun

Hasil pengamatan jumlah daun dapat dilihat pada Gambar 7. Jumlah daun setiap minggunya mengalami penambahan jumlah helai daun. Rata-rata penambahan jumlah helai daun pada minggu pertama sebanyak 3 helai, pada minggu kedua sebanyak 5 helai, dan pada minggu ketingga sebanyak 10 helai. Jumlah daun merupakan indikator pertumbuhan tanaman. Tetapi tidak seperti tinggi tanaman yang ukurannya tidak dapat berkurang tiap harinya, untuk jumlah daun dapat berkurang atau bertambah setiap harinya. Pengurangan jumlah daun dapat disebabkan oleh daun yang menguning dan akhirnya kering atau dimakan oleh hama tanaman (Yulita, 2014).

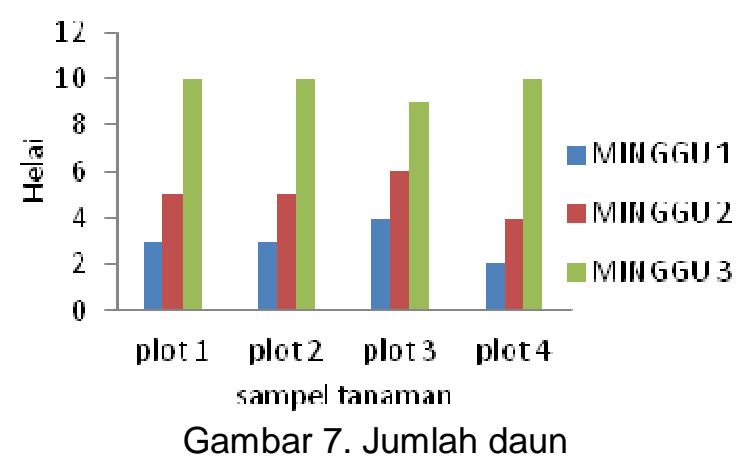

3) Indeks Luas Daun

Rata-rata indeks luas daun adalah 1.7 (Gambar 8). Pada plot empat memiliki indeks luas tanaman tertinggi sebesar 2.25 hal ini dikarenakan kecepatan angin pada saat penyiraman mengarah ke barat dimana letak plot empat berada. Letak lokasi plot empat jauh dari sprinkler namun dapat menghasilkan indeks luas daun yang lebih tinggi dari plot lainnya kerena pada plot empat menerima jumlah air irigasi yang lebih banyak. Selain itu, menurut Perwitasari et al., (2012) cahaya yang diterima tanaman dengan indeks luas daun besar akan lebih banyak dibandingkan dengan tanaman yang memiliki indeks luas daun kecil. Indeks luas daun yang besar pada suatu lahan yang luas belum tentu menunjukkan bahwa setiap tumbuhan mampu menyerap energi matahari secara efektif. Hal ini terjadi karena antara daun yang satu dengan lainnya dapat

34 Aplikasi Irigasi Portable Sprinkler Pada Tanaman Pakcoy (Brassica Juncea L.) Di Desa Marga Agung Kecamatan Jati Agung Lampung Selatan 
saling menaungi, sehingga tidak mendapatkan sinar matahari secara penuh.

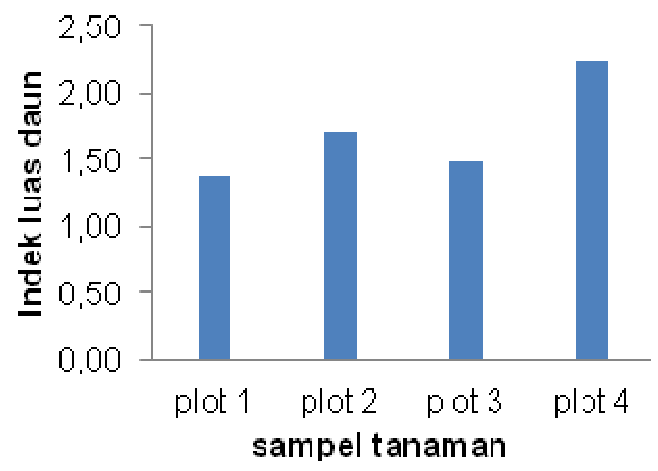

Gambar 8. Indeks luas daun

4) Hasil Produksi Tanaman Pakcoy

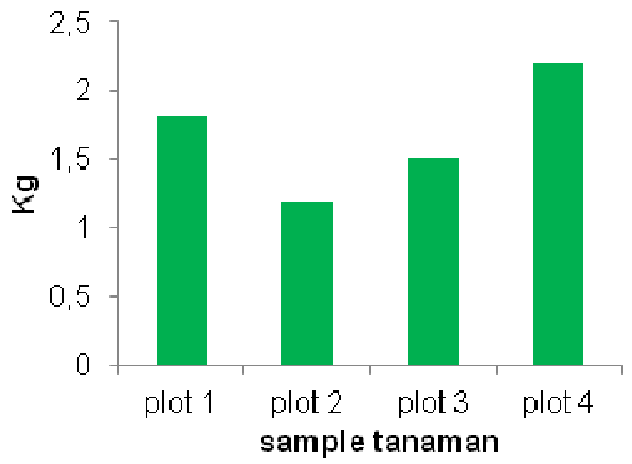

Gambar 9. Hasil panen tanaman pakcoy

Gambar 9, menunjukan bahwa hasil panen tertinggi adalah plot empat $2.2 \mathrm{~kg} / \mathrm{m}^{2}$, plot satu sebesar $1.8 \mathrm{~kg} / \mathrm{m}^{2}$, plot tiga sebesar $1.7 \mathrm{~kg} / \mathrm{m}^{2}$ dan plot dua sebesar $1.2 \mathrm{~kg} / \mathrm{m}^{2}$. Hasil produksi tanaman menghasilkan jumlah produksi yang tinggi setiap plot, hal ini menunjukkan bahwa pemberian air dapat diserap secara optimum. Hal ini sesuai dengan pernyataan Mechran (2006), besarnya air yang diserap oleh akar tanaman sangat tergantung pada kadar air tanah. Kisaran kadar air tanah yang tersedia secara optimum berada antara kapasitas lapang dan titik layu permanen.

Produksi tanaman pada plot empat menghasilkan jumlah produksi yang lebih tinggi dibandingkan plot yang lainnya, mulai dari tinggi tanaman, jumlah daun, dan indeks luas daun. Hal ini terjadi karena pada saat penyiraman arah angin lebih sering mengarah ke barat dengan kecepatan angin rata-rata
$0.66 \mathrm{~m} /$ det. Sedangkan tata letak plot empat berada di bagian barat pada saat penelitian, sehingga kebutuhan air pada plot empat tercukupi dibandingkan dengan plot yang lainnya.

Dari hasil wawancara dengan salah satu petani sayuran yaitu Bapak Dardi (44 tahun) mengatakan bahwa hasil produksi tanaman pakcoy dengan metode irigasi menggunakan gembor rata-rata hasil produksi tanaman pakcoy per meter adalah $4.2 \mathrm{~kg} / \mathrm{m}^{2}$ dengan total tanaman sebanyak 100 tanaman $/ \mathrm{m}^{2}$ lebih besar dibandingkan dengan hasil produksi menggunakan irigasi sprinkler sebesar 1.7 $\mathrm{kg} / \mathrm{m}^{2}$. Besarnya produksi tanaman dipengaruhi oleh pemupukan pada awal penanaman, penambahan nutrisi ketika penanaman, dan jarak tanam yang hanya 10 $\mathrm{cm} \times 10 \mathrm{~cm}$. Namun jika dilihat berat produksi per tanaman, berat tanaman dengan irigasi sprinkler dan jarak $20 \mathrm{~cm} \times 20 \mathrm{~cm}$ lebih besar dibanding jarak tanamaan $10 \mathrm{~cm} \times 10 \mathrm{~cm}$. Berat per tanaman pada lahan irigasi sprinkler adalah $70 \mathrm{gram} / \mathrm{tanaman}$ sedangkan berat pertanaman pada lahan konvensional adalah 40 gram/tanaman. Hal tersebut menunjukkan bahwa dengan irigasi sprinkler dan jarak tanam yang lebih renggang menghasilkan bobot tanaman lebih tinggi.

\section{KESIMPULAN DAN SARAN}

\section{Kesimpulan}

Berdasarkan hasil penelitian dengan menggunakan irigasi sprinkler portable pada tanaman pakcoy, tidak terjadi aliran permukaan (run off) karena laju penyiraman lebih kecil dari pada laju infiltrasi. Laju penyiraman adalah $6.49 \mathrm{~mm} / \mathrm{jam}$ dan laju infiltrasi $52 \mathrm{~mm} / \mathrm{jam}$. Nilai koefisien keseragaman penyiraman (CU) sebesar $53.13 \%$ dari total penggunaan air selama penanaman. Sedangkan produksi tanaman pakcoy pada lahan dengan irigasi sprinkler adalah 70 gram/tanaman lebih besar dibandingkan dengan berat tanaman pada lahan konvensional adalah 40 gram/tanaman.

\section{Saran}

Penelitian lebih lanjut dapat dilakukan dengan dua jaringan pipa lateral, agar nilai 
keseragaman curahan lebih tinggi (>85\%) menggunakan metode block square method.

\section{DAFTAR PUSTAKA}

Hansen, V.E., O.W. Israelsen, dan G.W. Stringham. 1992. Diterjemahkan oleh Tachyan dan Soetjipto. Dasar-Dasar dan Praktek Irigasi. Erlangga. Jakarta. 407 hal.

Intan, N. 2014. Evaluasi Kinerja Penggunaan Air Irigasi Sprinkler Studi Kasus Di Kabupaten Enrekang. Skripsi. Jurusan Teknik Pertanian. Fakultas Pertanian. Universitas Hasanuddin. http://repository.unhas.ac.id/bitstream/ha ndle/123456789/9041/skripsi\%20intan.p df?sequence $=1$. Diakses 7 Januari 2015 jam 11.30 WIB.

LPT (Lembaga Penelitian Tanah). 1979. Penuntun Analisa Fisika Tanah. Lembaga Penelitian Tanah, Bogor.

Mechran, S. 2006. Aplikasi Teknik Irigasi Tetes Dan Komposisi Media Tanam Pada Tanaman Selada. Jurnal Teknologi Pertanian, Vol. 7 No. 1:27 36.
Nining, A. F. 2015. Pemetaan Laju Infiltrasi Menggunakan Metode Horton Di Sub Das Tenggarang Kabupaten Bondowoso. (Skripsi) Jurusan Teknik Sipil Universitas Jember.

Perwtasari, B., M. Tripatmasari, dan C. Wasonowati. 2012. Pengaruh Media Tanam Dan Nutrisi Terhadap Pertumbuhan Dan Hasil Produksi Tanaman Pakchoi (Brassica juncea L.) Dengan Sistem Hidroponik. Jurnal Agrovigor, Vol. 5 No. 1:14-25.

Sutanto, R. 2005. Dasar-Dasar IImu Tanah. Kanisius. Yogyakarta. 208 hal.

Tusi, A. 2013. Rancang Bangun Sistem Irigasi Sprinkler Portable. Laporan Penelitian Teknik Pertanian. UNILA: Lampung.

Yulita, D.N. 2014. Pengaruh Lama Aerasi Terhadap Pertumbuhan Dan Hasil Tanaman Sawi (Brassica juncea L.) Pada Hidroponik DFT (Deep Flow Technique). Skripsi. Jurusan Teknik Pertanian. Fakultas Pertanian. Universitas Lampung. 